\title{
Utjecaj političkih institucija na veličinu državne potrošnje zemalja članica Europske unije i Hrvatske
}

Vučković, Valentina; Basarac Sertić, Martina

Source / Izvornik: Odabrani prijevodi, 2013, 4, 1 - 15

Journal article, Published version

Rad u časopisu, Objavljena verzija rada (izdavačev PDF)

https://doi.org/10.3326/op.15

Permanent link / Trajna poveznica: https://urn.nsk.hr/urn:nbn:hr:242:380497

Rights / Prava: Attribution-NonCommercial-NoDerivatives 4.0 International/ImenovanjeNekomercijalno-Bez prerada 4.0 međunarodna

Download date / Datum preuzimanja: 2023-04-26

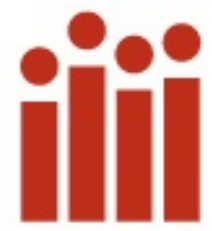

Repository / Repozitorij:

Institute of Public Finance Repository

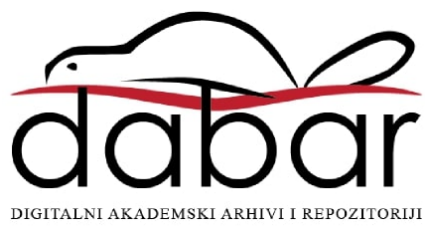


Institut za

javne financije

Smičiklasova 2I | Zagreb

www.ijf.hr | ured@ijf.hr

T: oI/4886-444 | F: OI/4819-365

\section{Odabrani PRIJEVODI}

ISSN $1847-7445$

\section{BR. I5/13}

citirati: Vučković, V. i Basarac Sertić, M., 20I3. "The effect of political institutions on the size of government spending in European Union member states and Croatia”. Financial Theory and Practice, 37 (2), I6I-I79. http://www.fintp.hr/upload/files/ft p/2013/2/vuckovic_basarec.pdf

Svi Odabrani prijevodi dostupni su na: http://www.ijf.hr/hr/publikacije/ca sopisi/I2/odabrani-prijevodi/III/

\section{UTJEGAJ POLITIČKIH INSTITUCIJA NA VELIČINU DRŽAVNE POTROŠNJE ZEMALJA ČLANICA EUROPSKE UNIJE I HRVATSKE}

\author{
VALENTINA VUČKOVIĆ \\ MARTINA BASARAC SERTIĆ*
}

PRETHODNO PRIOPĆENIE

JEL: D72, HII, E62

DOI: $10.3326 /$ op.15

\section{SAŽETAK}

Rad pruža pregled teorijskih i empirijskih istraživanja interakcije političkih institucija i ekonomskih varijabli te ekonometrijsku analizu indirektnog utjecaja izbornih sustava na veličinu potrošnje opće države. U radu je obavljena panel analiza za razdoblje od 1995. do 2010. godine na uzorku 25 zemalja članica Europske unije i Hrvatske. Rezultati istraživanja ukazuju da fragmentacija vlade $i$ stabilnost političkog sustava utječu na kretanje proračunskih rashoda u skladu s teorijskim postavkama. Kada je riječ o implikacijama istraživanja za Hrvatsku, pokazano je da veća fragmentiranost vlade vodi rastu državne potrošnje. To je važan rezultat jer je Hrvatska uglavnom imala neki oblik koalicijske vlade.

Ključne riječi: političke institucije, fiskalna politika, izborni sustavi, fragmentacija vlade, politička konkurencija, stabilnost političkog sustava

"Autorice zahvaljuju dvojici anonimnih recenzenata na korisnim komentarima i sugestijama.

"* Primljeno: I. lipnja 2012.

Prihvaćeno: 14. siječnja 2013.

Rad je bio prijavljen za godišnju nagradu "Zaklade prof. dr. Marijan Hanžeković” za 2oI2. godinu.

\section{Valentina VUČKOVIĆ}

Institut za razvoj i međunarodne odnose, Ljudevita Farkaša Vukotinovića 2, Ioooo Zagreb

e-mail: valentina@irmo.hr

Martina BASARAC SERTIĆ

Hrvatska akademija znanosti i umjetnosti, Strossmayerov trg 2, Ioooo Zagreb

e-mail: mbasarac@hazu.hr 


\section{UVOD}

Korelacija političkih institucija i gospodarskog razvoja jedno je od najzanimljivijih područja istraživanja na granici između ekonomskih i političkih znanosti (Persson i Tabellini, 20o6). Naime, suvremeni političko ekonomski modeli koji vladu vide kao endogenog čimbenika u političkom i ekonomskom sustavu, u kontrastu su s tradicionalnim pristupom koji kreatora ekonomske politike vidi kao benevolentnog planera koji procjenjuje interese svih članova društva i čiji je jedini cilj maksimizacija društvenog blagostanja (Snowdon i Vane, 2005:30). U okviru spomenutih modela, ekonomska politika se ne kreira neovisno o utjecaju različitih aspekata političkih institucija, već se vlada koja je odgovorna za kreiranje i provedbu ekonomske politike nalazi u središtu interakcije između političkih i ekonomskih faktora. Međutim, pri tome je ponašanje vlade određeno raznim institucionalnim ograničenjima koja čine politički sustav (Snowdon i Vane, 2005:52I). Prema pristupu političke ekonomije, ekonomska politika je prepuna sukoba interesa (Roberts Clark, Golder i Nadenichek Golder, 2009), a politički sustav je sredstvo za rješavanje tih konflikata. Ti konflikti neizbježno se javljaju jer društva čine pojedinci i grupe sa specifičnim vrijednostima i interesima koji su rezultat njihovih različitih zanimanja, izvora dohotka, ideologije i sl. (Persson i Tabellini, 2004b). U tom kontekstu Persson, Roland i Tabellini (200o) identificiraju tri temeljna sukoba interesa. Prvo, kreatori politike mogu zloupotrijebiti političku moć i prisvojiti sredstva iz javnih fondova na štetu birača. Drugo, birači dolaze u sukob po pitanju alokacije poreznih prihoda; i treće, političari (slijedeći osobne interese) međusobno dolaze u sukob oko distribucije dostupnih i budućih renti. Ključnu ulogu u razrješenju tih sukoba imaju političke institucije koje se javljaju u više dimenzija. Cilj je ovog rada utvrditi dimenzije izbornog sustava koje neposredno i/ili posredno utječu na veličinu potrošnje opće države. U svrhu ostvarenja cilja u radu se testira utječu li veća fragmentacija vlade, politička konkurencija i stabilnost političkog sustava na dinamiku državne potrošnje.

\section{UTJEGAJ IZBORNIH SUSTAVA NA ISHODE FISKALNE POLIT'TKE: T'EORIJSKI OKVIR}

U posljednjih dvadeset godina u političkoj ekonomiji povećao se broj radova koji se bave utjecajem političkih institucija na ishode fiskalne politike (Milesi-Ferreti, Perotti i Rostagno, 2002; Persson i Tabellini, 2000, 2003, 2004a; Persson, 2002; Persson, Roland i Tabellini, 2003; Voigt, 2009; Gregorini i Longoni, 2OIO; Acemoglu, 2005; Blume et al., 2007; Hallerberg i von Hagen, 1997; itd.), čime se uvelike unaprijedilo razumijevanje političko-ekonomskih odnosa u društvu. U većini istraživanja predmetom analize su dvije kategorije političkih institucija: izborni sustavi i oblici vlasti. Iako nema jedinstvenog konsenzusa po pitanju njihovog utjecaja, općenito se smatra da parlamentarni oblik vlasti (gdje se zastupnici biraju u okviru razmjernih izbornih sustava) karakterizira veća javna potrošnja i porezi, veća socijalna država, veći proračunski deficit i javni dug. Predsjednički ili parlamentarni oblik vlasti (gdje se parlament i vlada formiraju na temelju većinskog izbornog sustava) karakterizira manja državna potrošnja, manji porezi, manja socijalna država i uravnoteženi proračun. Dakle, ishodi fiskalne politike nameću se kao logičan izbor za zavisne varijable. U brojnim se istraživanjima koriste varijable poput poreznih prihoda; veličine i strukture državne potrošnje; proračunskog salda i javnog duga. 
Predmet istraživanja ovog rada su izborni sustavi koji podrazumijevaju skup pravila za izbor političkih kandidata te upravljanje njihovim funkcijama, a razlikuju se veličina izbornog okruga, izborni obrazac te struktura glasovanja (Persson i Tabellini, 2004b). Veličina izbornog okruga podrazumijeva broj mandata (zastupnika) u okrugu, pri čemu se razlikuju jednomandatni i višemandatni okruzi. Veličina okruga utječe na stupanj razmjernosti i reprezentativnosti (tj. predstavništva relevantnih društvenih

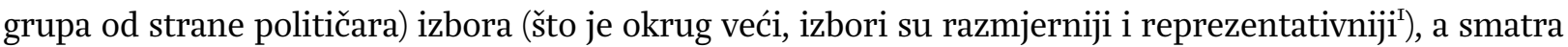
se politički najučinkovitijom dimenzijom izbornih sustava kojom se najviše manipulira (Kasapović, 2003:I52). Veći izborni okrug širi izbornu konkurenciju, te potiče stranke da traže podršku u širim koalicijama birača. To generira veće i šire fiskalne programe. Manji okrug usmjerava izbornu konkurenciju prema geografski užim izbornim jedinicama inducirajući veći broj specifičnih programa (Klašnja, 2008). Izborni obrazac smatra se najvažnijim aspektom izbornog sustava, a obuhvaća pravila i metode odlučivanja o izbornom pobjedniku (odnosno način pretvaranja glasova u mandate) ${ }^{2}$, pri čemu se razlikuju većinski i razmjerni izbori (Persson i Tabellini, 2004b). Političari ne moraju uzeti u obzir preferencije i interese svih birača, nego trebaju primarno zadovoljiti one birače koji će im osigurati pobjedu na izborima (Klašnja, 2008). Kod većinskog izbornog obrasca niži je potreban postotak ukupnih glasova za pobjedu na izborima nego kod razmjernog sustava, pa se državna potrošnja usmjerava prema manjim i geografski koncentriranijim grupama birača ${ }^{3}$, a preferiraju se lokalna javna dobra, dotacije iz državne blagajne koje političari upućuju svojoj regiji ili lokalnoj zajednici (engl. pork-barrel spending) (Persson i Tabellini, 2003; Milesi-Feretti, Perotti i Rostagno, 2002). S druge strane, kod razmjernog sustava, političari nastoje internalizirati koristi za veći dio stanovništva, što dovodi i do veće državne potrošnje koja se temelji na transferima i subvencijama koje koriste većim grupama stanovništva (Persson i Tabellini, 2003). Struktura glasanja kao treća dimenzija izbornih sustava, određuje način na koji glasači odlučuju i iskazuju preferencije prema političkim kandidatima ili izbornim listama. Ta dimenzija političkih sustava utječe na fiskalnu politiku kroz odgovornost političkih kandidata prema biračima te osjetljivost birača na učinkovitost stranke na vlasti (Klašnja, 2008). Većinski (razmjerni) izborni sustavi oslanjaju se na individualne kandidate (izborne liste). Kod razmjernog sustava temeljenog na izbornim listama, uz smanjenu odgovornost političara prema biračkom tijelu, može se očekivati da kandidati manje investiraju u svoje kampanje zbog čega se može pojaviti problem slobodnog “švercera” (engl. free rider), lobiranja (engl. rent-seeking) i korupcije (Voigt, 20og; Persson i Tabellini, 2000, 2003). Sve to može voditi pretjeranoj rasipnosti nositelja politike te posljedičnog pritiska na povećanje poreza (Persson i Tabellini, 2003). Iako se opisane dimenzije međusobno razlikuju, u praksi su često korelirane. Tako zemlje s većinskim izbornim sustavom imaju minimalni broj izbornih jedinica i omogućuju glasanje za pojedinačne kandidate. Zemlje s razmjernim sustavom često imaju veći broj izbornih jedinica te se oslanjaju na izborne liste (Voigt, 2009). Očito je da između

\footnotetext{
${ }^{\mathrm{I}}$ Veći izborni okrug povećava broj kandidata u političkom procesu (koji mogu proizvesti niže ravnotežne rente), ali i glasači mogu kazniti korumpirane stranke uz niži ideološki trošak (Persson, 2002).

${ }^{2}$ Izborni obrazac određuje minimalni broj glasova potrebnih za pobjedu pri čemu je pod većinskim sustavom potreban postotak ukupnih glasova niži nego kod razmjernog sustava. Većinski izborni sustav je utemeljen na većinskom pravilu (izborni pobjednik se bira relativnom ili apsolutnom većinom glasova birača); dok je razmjerni izborni sustav utemeljen na načelu pravednog političkog predstavljanja biračkog tijela i raspodjeli mjesta u predstavničkom tijelu koja je razmjerna broju glasova za izborne aktere (Kasapović, 2003).

${ }^{3}$ Drugim riječima, političari se više fokusiraju na tzv. swing birače.
} 
ova dva sustava postoji i određeni međuprostor u kojem niti jedan ne osigurava bolje ishode u odnosu na drugi. Razmjerni sustavi su reprezentativniji i također dovode do veće potrošnje, traganja za rentama i redistribucije u korist većine. Većinske sustave obilježava redistribucija u korist manjinskih društvenih grupa, manja potrošnja te veća odgovornost političara prema biračima (Klašnja, 2008).

Izborni sustavi mogu i indirektno utjecati na fiskalnu politiku kroz svoj utjecaj na oblikovanje strukture političkih stranaka, na političku konkurenciju, kao i na političku stabilnost (vidi Persson i Tabellini, 2006; Persson, Roland i Tabellini, 2003; Baraldi, 2007; Gregorini i Longoni, 20IO; Padovano i Venturi, 200I). Primjerice, razmjerni izborni sustav povezan je s fragmentiranijim stranačkim sustavom, uz češće koalicijske vlade, dok većinski izborni sustavi češće rezultiraju jednostranačkim vladama. Stoga bi bilo čudno ako se ti učinci ne odraze i u ekonomskim politikama koje su primijenjene unutar različitih stranačkih sustava i tipova vlasti. Općenito, uz veću fragmentaciju vlade, može se očekivati veća državna potrošnja te usmjeravanje iste na heterogenije grupe stanovništva (Gregorini i Longoni, 20Io). Detaljniji opis povezanosti između navedenih dimenzija i državne potrošnje dan je u okviru ekonometrijske analize budući da su upravo te kategorije političkih institucija uključene u model.

\section{PREgled EMPIRIJSKIH ISTRAŽIVANJA I METODOLOŠKIH PROBLEMA}

Iako s empirijskog stajališta i dalje predstoje brojni izazovi, dosadašnja istraživanja najčešće su potvrđivala značajnost utjecaja političkih institucija na kreiranje ekonomske politike. Primjerice, Persson i Tabellini (2003), su proveli istraživanje na uzorku od 85 zemalja za period od 1960-1998. godine te pokazali da je ukupna potrošnja središnje države $u$ razmjernim izbornim sustavima $u$ prosjeku veća za otprilike 4-5\% BDP-a nego u većinskim sustavima. Autori također potvrđuju da reforma izbornog sustava s razmjernog na većinski, dovodi do smanjenja izdataka za socijalno osiguranje u prosjeku za oko 2-3\% BDP-a, te smanjenja proračunskog deficita za I-2\% BDP-a. Nadalje, Milesi-Ferretti, Perotti i Rostagno (2002) istražuju utjecaj izbornih sustava na veličinu i sastav državne potrošnje na uzorku od 20 zemalja Organizacije za ekonomsku suradnju i razvoj (engl. Organization for Economic Co-operation and Development - OECD) i 20 zemalja Latinske Amerike. Njihovi rezultati su također pokazali da razmjerni izborni sustav (u odnosu na većinski) karakteriziraju veća ukupna državna potrošnja, ali i veća transferna plaćanja. Proširujući analizu Perssona i Tabellinija, Blume et al. (2007) pokazuju da je potrošnja središnje države u prosjeku za 7\% niža u većinskom nego u razmjernom izbornom sustavu te ističu da su veličina okruga i udio individualno izabranih kandidata značajniji faktori od samih izbornih sustava. Osim toga, Persson i Tabellini (2006:729) analiziraju direktne i indirektne učinke ističući da izborni sustav utječe na državnu potrošnju samo indirektno, odnosno kroz strukturu stranaka i tip vlade. Konačno, Gregorini i Longoni (20I0) u svojem radu kontroliraju i učinke distribucije mjesta unutar određene vlade uvodeći u analizu i Herfindahl Government Index koji omogućuje analizu učinka fragmentiranosti vlade na državnu potrošnju. Naime, kako ističu i autori, postoje zemlje s razmjernim izbornim sustavom i niskom fragmentacijom (i obrnuto) pa je zanimljivo istražiti razlike između stupnja fragmentiranosti vlada (čak i unutar dvije kategorije izbornih sustava) te njihov utjecaj na preferencije kreatora politike po pitanju javne potrošnje. Autori tvrde da se uz veću fragmentaciju vlade, potrošnja usmjerava na heterogenije grupe stanovništva. Roubini i Sachs (I989) su 
također pokazali da više fragmentirane vlade karakterizira veći deficit i javni dug (u OECD zemljama), i to prvenstveno zbog sklonosti takvih vlada pretjeranoj potrošnji bilo zbog različitih interesa i izbornih jedinica, veto moći nad donošenjem proračuna ili slabih mehanizama za provedbu obvezujućih sporazuma među koalicijskim partnerima.

Poterba (1994) na uzorku od 50 saveznih američkih država potvrđuje da fiskalne institucije i politički čimbenici utječu na dinamiku kretanja proračunskog deficita (u kratkom roku). Države u kojima je jedna stranka $u$ vladi i parlamentu brže reagiraju na neočekivani deficit u odnosu na države $u$ kojima jedna stranka dominira u vladi, a druga u parlamentu. Hallerberg i von Hagen (1997) analiziraju utjecaj izbornog sustava i broja stranaka na ishode fiskalne politike te zaključuju kako delegiranje od strane “jakog” ministra financija ili obveza ugovaranja proračunskih ugovora može imati značajan utjecaj na rast proračunskog deficita. Navedene institucije su osobito efikasne $u$ održavanju deficita niskima $u$ zemljama s nekim oblikom političke nestabilnosti. Nadalje, Hallerberg i von Hagen (1997) navode da države koje žele smanjiti svoje deficite trebaju odabrati jednu od spomenutih proračunskih institucija temeljenu na obliku vlade - ili jednostranačku većinsku vladu ili višestranačku koalicijsku vladu (pri čemu je jednostranačka vlada prikladnija za delegiranje, dok se višestranačka bazira na obvezi). Nadalje, usporedba različitih sustava i rješenja koja se trenutno primjenjuju indicira da se, pod određenim uvjetima, uloga "jakog” ministra financija može proširiti višestranačkom vladom. Međutim, ključno je pri tome da sve stranke u vladi imaju na umu da im je izborna sudbina jednaka. Alesina et al. (I999) također naglašavaju značajnost razlika u fiskalnim rezultatima među zemljama, pri čemu navedene razlike objašnjavaju fokusirajući se na procedure s aspekta kreiranja, odobrenja i implementacije proračuna. Analizirajući utjecaj izbornih sustava i proračunskih procesa na uzorku od 20 latinoameričkih zemalja i Kariba (u razdoblju od 1980. do 1992. godine), pokazuju da transparentne i hijerarhijske proračunske procedure ${ }^{4}$ vode nižoj razini deficita.

Dok su pojedini rezultati konzistentni s teorijskim predviđanjima, drugi zahtijevaju detaljniju analizu, a postoje i određene kritike na primijenjene ekonometrijske alate koji su osjetljivi na veličinu uzorka, vremensko razdoblje kao i na same političke varijable koje se koriste. Prvo, kritike o izboru zemalja u uzorak temelje se na pitanju ideologije vlade. Pretpostavlja se da su razmjerni izborni sustavi povezani s ljevičarskim strankama koje zastupaju interese birača s niskim dohocima, dok su desničarske vlade koje zastupaju interese birača s visokim dohocima češće pod većinskim izbornim sustavom (Roberts Clark, Golder i Nadenichek Golder, 2009:713-715). Ta bi pretpostavka mogla objasniti zašto su rashodi pod razmjernim sustavom veći. U slučaju da se tip izbornog sustava određuje na temelju politika koje će kreatori ekonomske politike primjenjivati, to bi moglo objasniti njihovu korelaciju s ideologijom. Tamo gdje dominiraju birači ljevice, izabrao bi se razmjerni sustav, dok bi se većinski sustav izabrao tamo gdje dominira desnica. Međutim, Persson i Tabellini (2004b) tvrde da čak i ako izborni sustavi utječu na politiku kroz ideologiju vlade (a ne npr. kroz broj stranaka u vladi), tada izborni sustav sam po sebi ne bi bio dobar instrument u regresiji za državne rashode. Sveobuhvatne kritike najčešće korištenih metoda kao i izbora varijabli pobrojao je Acemoglu (2005), a najveće kritike dolaze s aspekta

\footnotetext{
${ }^{4}$ Alesina i Perotti (I999) su istaknuli da su hijerarhijske proračunske procedure analogne većinskim izbornim sustavima.
} 
primjene metode najmanjih kvadrata koja se oslanja na egzogenost političkih institucija. On smatra da iako rezultati ove metode otkrivaju zanimljive uzorke, oni ne identificiraju uzročno-posljedične utjecaje budući da su same političke institucije određene različitim društvenim faktorima koji u modelima nisu potpuno kontrolirani. Stoga, predlaže alternativni pristup u okviru kojeg bi političke institucije zapravo trebale biti endogene, odnosno određene istim faktorima koji imaju direktni utjecaj i na ishode ekonomske politike ${ }^{5}$.

Dok veći broj istraživanja uključuje u uzorak veliki broj zemalja koje se razlikuju prema ekonomskim, geografskim, društvenim i kulturološkim razlikama, zanimljivo je fokusirati se i na pojedinačne homogenije grupe zemalja. Dakle, istraživanje utjecaja političkih institucija ostavlja dovoljno prostora za daljnje analize, budući da su mnoga saznanja još uvijek preliminarna i predmet su brojnih rasprava. Specifično, Persson i Tabellini (2003) ističu da bi nova istraživanja trebala krenuti u smjeru boljeg razumijevanja detaljnih mehanizama utjecaja političkih institucija na kreiranje ekonomske politike. Naime, dosadašnji način komparativnog istraživanja zanemaruje vezu između izbornih sustava, stranačke strukture, formiranja vlade te kreiranja fiskalne politike.

Analizom literature prikazan je proces odlučivanja koji se razlikuje od idealnog modela postavljenog u okviru normativne teorije budući da vlada ne djeluje nužno u općem interesu nego može biti u funkciji raznih agenata (tzv. state capture) te dovesti do različitih učinaka na društvene grupe (Acocella, 2005; Hellman i Schankerman, 200o). Rasprave o reformama izbornih sustava prisutne su od 199o-ih godina $\mathrm{i}$ to ne samo u zemljama karakteriziranima kao "nove demokracije" već i zemljama poput Ujedinjenog Kraljevstva, te su do sada i provedene primjerice u Novom Zelandu, Japanu i Italiji (Persson i Tabellini, 2004b). Međutim, ostaje otvorenim pitanje koja kombinacija različitih dimenzija je superiornija. U tom su kontekstu, doprinosi ekonomista raspravama o budućnosti političkih institucija na razini Europske unije relativno oskudni (Voigt, 2009).

\section{EMPIRIJSKA ANALIZA}

Proučavanje učinaka fiskalnih, a time i političkih institucija, potaknuto je potrebom za upravljanjem prekomjernom potrošnjom i deficitom u zemljama OECD-a i zemljama $u$ razvoju; te $s$ aspekta Europske unije (EU) pronalaskom odgovarajućeg skupa pravila za kreiranje nacionalnih fiskalnih politika u zemljama članicama (von Hagen, 2006). Važnost političkih institucija u kreiranju ekonomske politike sastoji se u činjenici da se institucijama koje utječu na odluke kreatora politike po pitanju javnih financija mogu ublažiti negativne posljedice principal-agent problema i problema zajedničke blagajne (engl. common pool problem) (von Hagen, 2006). Nadalje, Lohman (2006:523) ističe da ne samo da ekonomska politika iznimno odstupa od normativnih propisa ekonomske teorije, nego da se i ekonomske performanse mijenjaju tijekom vremena i razlikuju među zemljama do stupnja kojeg ekonomski faktori ne mogu objasniti. Pitanje je dakle, mogu li politički čimbenici - kolektivno djelovanje i političke institucije - objasniti uzroke navedenih razlika. Stoga će se u ovom dijelu rada

\footnotetext{
${ }^{5}$ Racionalni agenti bi trebali razumjeti (i imati određene preferencije) ne samo implikacije različitih ekonomskih politika nego i različitih političkih institucija (Acemoglu, 2005).
} 
empirijski istražiti teorijska predviđanja o utjecaju političkih institucija na ishode fiskalne politike u zemljama EU. Pri tome će analiza obuhvatiti ispitivanje indirektnog utjecaja izbornih sustava na udio potrošnje opće države u BDP-u. Posebnu važnost u ovom radu imat će primjena panel analize, koja obuhvaća razdoblje od 1995. do 20IO. godine, a provedena je za 25 zemalja članica Europske unije ${ }^{6}$ te Hrvatsku.

\section{SLIKA I.}

Udio ukupne potrošnje opće države u BDP-u (EU-27 prosjek), 1995-20IO.

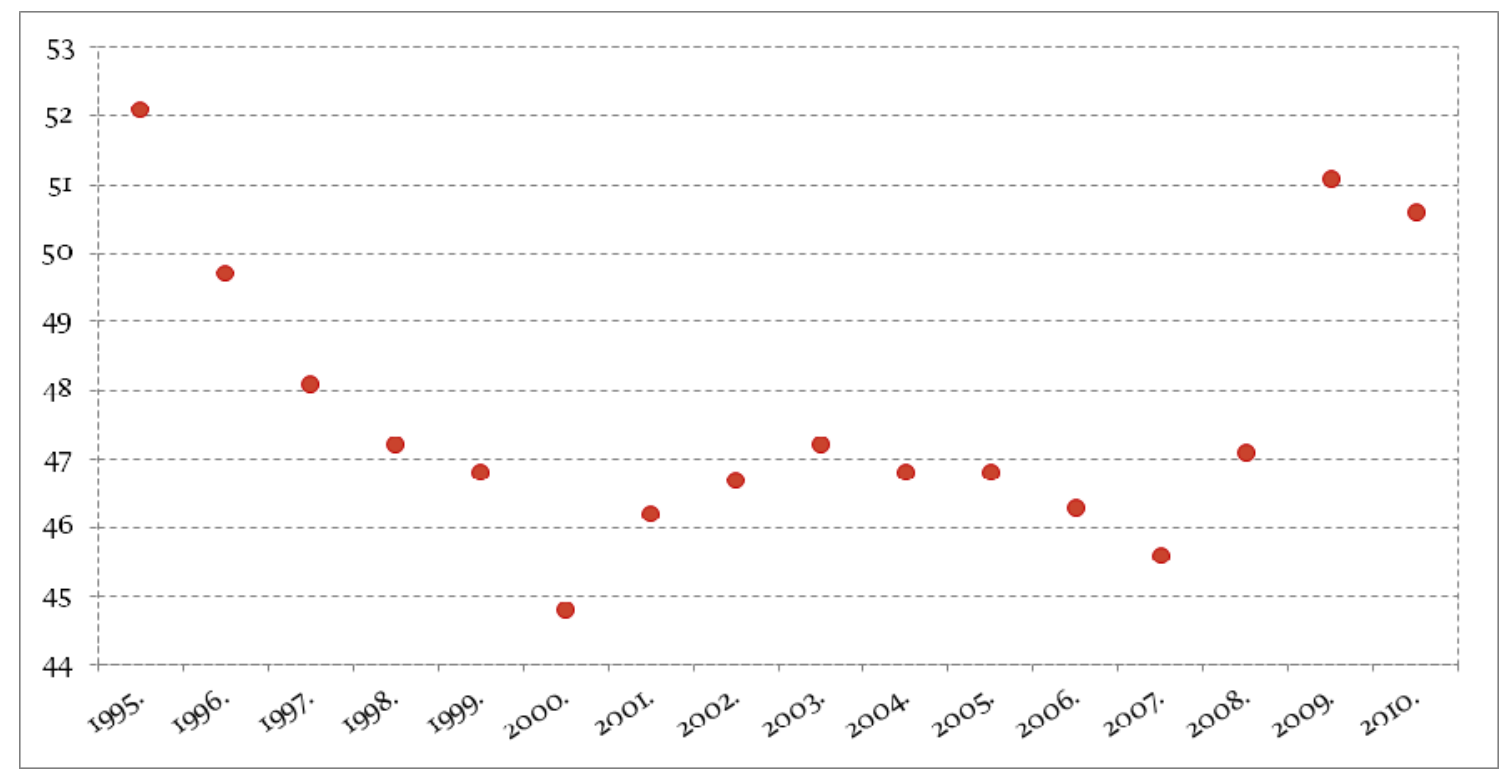

Izvor: Eurostat.

SLIKA 2.

Udio ukupne potrošnje opće države u BDP-u, prosjek za razdoblje 1995-20Io. (po zemljama)

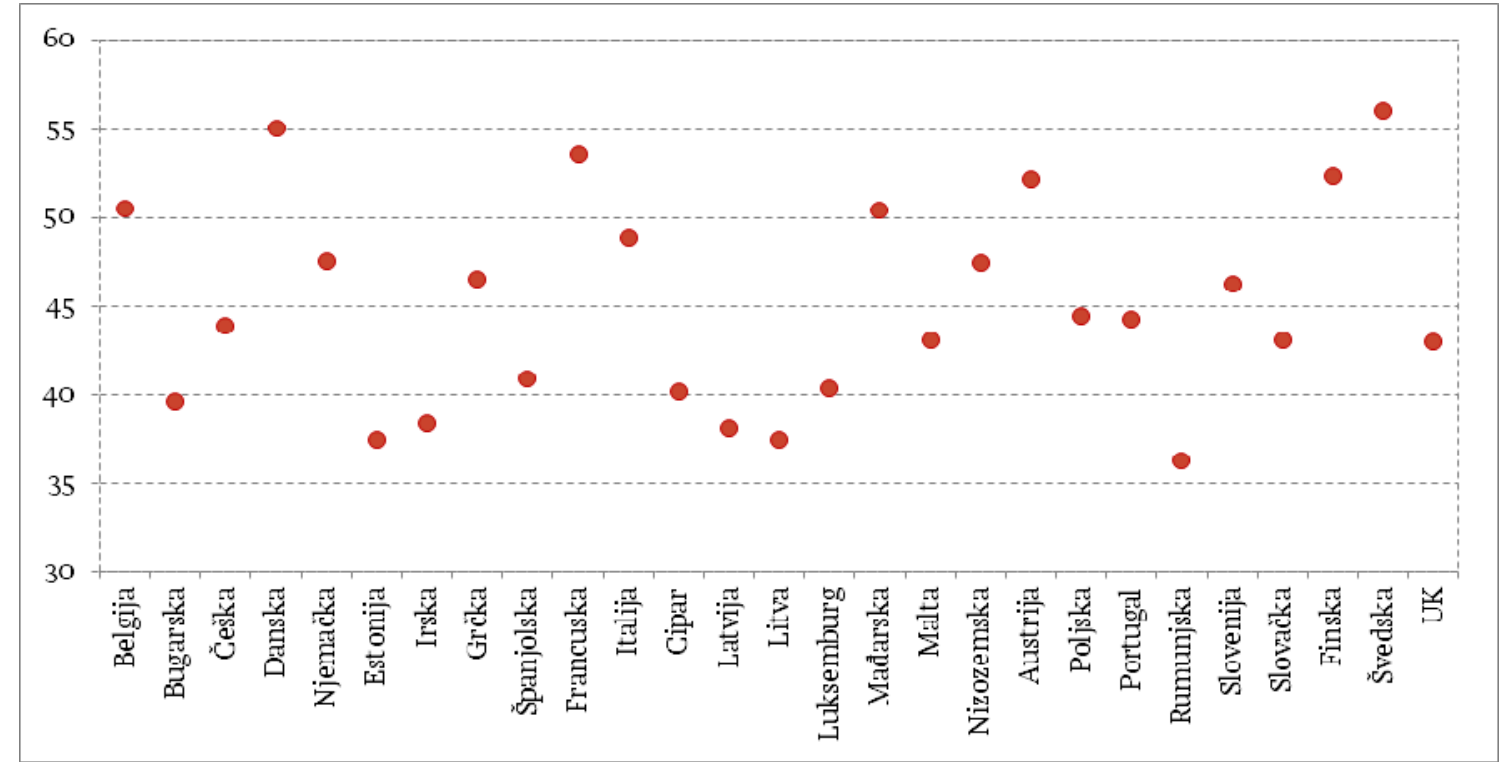

Izvor: Eurostat

${ }^{6}$ Austrija, Belgija, Bugarska, Cipar, Češka, Danska, Estonija, Francuska, Finska, Grčka, Irska, Italija, Latvija, Litva, Mađarska, Nizozemska, Njemačka, Poljska, Portugal, Rumunjska, Slovenija, Slovačka, Španjolska, Švedska i UK. 
Iz slike I. vidljivo je da je prosječna veličina države u zemljama EU-27 mjerena udjelom ukupne potrošnje opće države u BDP-u bez većih varijacija do 2008. godine kada bilježi značajniji porast. Međutim, na slici 2. razvidno je da se potrošnja u zemljama (prosjek za razdoblje 1995-2010.) kreće u rasponu od 35 do oko 55\% BDP-a. Na temelju ovakvih kretanja, proizlazi da veličina države varira među zemljama te nešto manje i kroz vrijeme.

Postavlja se dakle pitanje iz čega proizlazi prikazana varijacija ako se uzme u obzir da su se procesom EU integracije, nacionalne vlade članica EU obvezale slijediti određena pravila definirana za mjere makroekonomskih politika što je rezultiralo i implementacijom sličnih ekonomskih politika na nacionalnoj razini. Kao posljedica toga, zemlje su i implementirale slične makroekonomske politike na nacionalnoj razini. Jedan od potencijalnih odgovora koji se nameće na gore postavljeno pitanje je da političke institucije, koje su dugo smatrane egzogenima, imaju značajan utjecaj na kreiranje ekonomske politike. Tome u prilog ide i istraživanje Hallerberga, Straucha i von Hagena (2007) koji tvrde da iako su sve zemlje EU suočene $\mathrm{s}$ istim fiskalnim okvirom, postoje značajne varijacije u proračunskim institucijama na nacionalnoj razini, što pak proizlazi iz karakteristika njihovih političkih institucija. U Hrvatskoj, spomenuto je djelomice predmet istraživanja Rubil i Švaljek (20IO) koji, na temelju analize razvoja političkog sustava $\mathrm{u}$ Hrvatskoj, daju argumente $\mathrm{u}$ prilog upotrebe fiskalnih pravila; međutim broj detaljnijih radova o povezanosti između političkih institucija i ishoda fiskalne politike (prema saznanju autora) je oskudan.

S aspekta političkih institucija koje se najčešće istražuju u literaturi, sve zemlje osim Francuske i Ujedinjenog Kraljevstva imaju razmjerni izborni sustav?. Razlike će se stoga tražiti u specifičnim karakteristikama unutar kategorije izbornih sustava. Dakle, doprinos ovog rada literaturi očituje se upravo kroz analizu detaljnijih mehanizama, odnosno indirektnih utjecaja izbornih sustava (kroz fragmentiranost vlade, političku konkurenciju i političku stabilnost) na veličinu državne potrošnje. Osim toga, (prema Aidt i Eterovic, 2OII) analiza se provodi na homogenijoj grupi zemalja budući je većina istraživanja do sada $u$ isti uzorak uključivala veliki broj razvijenih i zemalja u razvoju koje se međusobno razlikuju s aspekta većeg broja ekonomskih, geografskih, kulturoloških i društvenih karakteristika.

\section{I. ODABIR MODELA I OPIS VARIJABLI}

U skladu s pregledom dosadašnjih spoznaja, u ovom će se dijelu rada na temelju Arellano-Bond (I99I) generalizirane metode momenata (engl. Generalized Method of Moments - GMM) procijeniti dinamički panel model $^{8}$ s nezavisnim varijablama $u$ jednom koraku. Naime, panel podaci obogaćuju empirijsku analizu na način koji ne bi bio moguć upotrebom samo prostorne ili vremenske dimenzije. Nadalje,

\footnotetext{
${ }^{7} \mathrm{~S}$ aspekta oblika vlasti sve zemlje osim Cipra, Poljske i Litve imaju parlamentarni sustav.

${ }^{8}$ Općenito, obzirom na karakteristike panel podataka razlikujemo statičke (združeni ili pooled modeli, modeli s fiksnim efektom i modeli sa slučajnim efektom) i dinamičke modele. Međutim, statički su panel modeli, robusni na korelaciju među opažanjima unutar jedne jedinice promatranja, stoga izbor odgovarajućeg panel modela nije jednostavan jer korelacija među opažanjima unutar jedne jedince promatranja mora biti konstantna bez obzira koliko ta opažanja vremenski bila udaljena (Škrabić, 20og). Naime, ovaj uvjet može biti ograničavajući budući da kod ekonomskih varijabli najčešće postoji korelacija između sadašnje vrijednosti varijable i njene vrijednosti u prethodnom periodu, pa ako se ovaj oblik korelacije zanemari i procijeni se "odgovarajući” statički model, procijenjeni parametri modela će biti konzistentni, ali neefikasni s pristranim standardnim greškama procjene (Škrabić, 2009).
} 
dinamički panel modeli u odnosu na statičke panel modele imaju široku ekonomsku primjenu jer čak i kada koeficijenti lagirane zavisne varijable nisu od izravnog interesa, omogućavanje dinamike može biti ključno za konzistentnu procjenu ostalih parametara (Bond, 2002). Pri tome je Arellano i Bond procjenitelj prikladan za analizu panela konstruiranih s malim T (broj razdoblja) i velikim $N$ (broj jedinica promatranja), što je karakteristika skupa podataka u ovom radu. Nadalje je ovaj procjenitelj prikladan za analizu linearne veze, u kojoj je zavisna varijabla dinamična, odnosno ovisna o vlastitim prošlim vrijednostima, te kada nezavisne varijable nisu strogo egzogene. Navedeni procjenitelj uzima $u$ obzir specifičnost svake jedinice promatranja i dozvoljava heteroskedastičnost i autokorelaciju unutar jedinica promatranja, ali ne i među njima (Roodman, 2006). Arellano i Bond procjena započinje transformacijom svih regresora, najčešće diferenciranjem, a koristi generaliziranu metodu momenata (Hansen, 1982).

Budući da u konkretnom modelu za sve zemlje nisu dostupni podaci za sve godine od interesa, za procjenu odgovarajućih modela koristit će se nebalansirani ${ }^{9}$ panel model. Spomenuti se model može zapisati na sljedeći način:

$$
y_{i t}=\mu+\delta y_{i, t-1}+\beta_{i} x_{i t K}+v_{i}+u_{i t}, i=\mathrm{I}, \ldots, \mathrm{N}, t=\mathrm{I}, \ldots, \mathrm{T},
$$

pri čemu $N$ označava broj jedinica promatranja, T označava broj razdoblja, $y_{i t}$ označava vrijednost zavisne varijable (u konkretnom slučaju to su ukupni izdaci opće države za 25 zemalja članica Europske unije i Hrvatsku, izraženi kao postotak BDP-a - exp) $i$ u razdoblju $t$, parametar $\mu$ je konstantni član, $\delta$ je skalar, $y_{i, t-1}$ je zavisna varijabla (za istu zemlju) s vremenskim pomakom unatrag za jedno razdoblje (godinu), $x_{i t 1}, \ldots, X_{i t K}$ su K nezavisnih varijabli (herfgov, polityIV, gdp_gr, pop i stabs) za zemlju članicu $i \mathrm{u}$ razdoblju $t$ (odnosno $x_{i t}^{\prime}$ je I $x$ Ki $\beta$ je K $x \mathrm{I}$ ), $v_{i}$ je fiksni efekt ili slučajna pogreška za jedinicu promatranja, a $u_{i t}$ je greška relacije. Pretpostavka modela je da su sve varijable $x_{i t}$ strogo egzogene u smislu da su nekorelirane s bilo kojim ${u_{i t}}^{\text {10 }}$. Kao proxy varijabla za fragmentaciju vlade koristi se Herfindhalov indeks ${ }^{\text {II }}$ (herfgov) koji predstavlja mjeru koncentracije vladajuće koalicije (prema Gregorini i Longoni, 20I0). U slučaju jednostranačke vlade, indeks je jednak I, dok je u slučaju koalicijske vlade vrijednost indeksa između o i I. Dakle, što je veći broj stranaka u koalicijskoj vladi, manja je vrijednost ovog indeksa, dok je prisutnost dominantne stranke povećava. S aspekta utjecaja na državnu potrošnju, što je veća fragmentacija (manji indeks), očekuje se povećanje državne potrošnje. Naime, što je veći broj stranaka u koaliciji, veća je vjerojatnost problema zajedničke blagajne pri čemu će svaka stranka nastojati zadovoljiti želje svojih birača (Persson i Tabellini, 2003). Odnosno, povećanje Herfindhalovog indeksa (zbog smanjenja broja stranaka zastupljenih unutar vlade), generira smanjenje

\footnotetext{
${ }^{9}$ Kod balansiranih modela panel podataka sve jedinice imaju svoju vrijednost u svakom razdoblju. $\mathrm{S}$ druge strane, kod nebalansiranih panel podataka za sve zemlje nisu dostupni podaci za svaku godinu od interesa.

${ }^{\text {Io }}$ Međutim, često se pretpostavka striktne egzogenosti zamjenjuje s pretpostavkom predeterminiranosti što znači da su trenutna vrijednost i vrijednost s pomakom svake nezavisne varijable nekorelirane s trenutnim vrijednostima grešaka relacije (Škrabić, 2009).

${ }^{{ }^{2}}$ Općenito, indeks se dobije kao zbroj kvadrata mjesta svih stranaka u vladi te na taj način pokazuje kako su raspoređena mjesta unutar vladajuće koalicije.
} 
državne potrošnje. Dakle, očekuje se negativni predznak uz ovu varijablu. Nadalje, polityIV se općenito interpretira kao mjera demokracije, međutim prema nekim autorima ova se varijabla interpretira kao mjera odnosno stupanj političke konkurencije do kojeg se različite političke stranke, interesne grupe ili druge organizirane frakcije unutar definirane političke strukture slobodno natječu za dobivanje političke moći (podrobnije vidjeti u Aidt i Eterovic, 20II). Pritom je veća politička konkurencija povezana s efikasnijom vladom (stranka na vlasti ima poticaje za boljim performansama kako bi bila ponovno izabrana na vlast), pa se u tom slučaju očekuje negativni predznak uz državne rashode (Aidt i Eterovic, 20II; Besley, Persson i Sturm, 20IO) ${ }^{I 2}$. S druge strane, u situaciji kad je vjerojatnost ponovnog izbora na vlast niska, političari se mogu ponašati i oportunistički pa se može očekivati i povećanje državne potrošnje kako bi "kupili" glasove birača. Konačno, varijabla stabs je pokazatelj stabilnosti političkog sustava, a definirana je kao udio veto aktera koji izađu iz vlade u bilo kojoj godini (Beck et al., 20oI). Predznak uz ovu varijablu može biti pozitivan i negativan: dok se općenito drži da stabilniji politički sustav karakterizira manja državna potrošnja (Devereux i Wen, 1998), veća stabilnost sustava također može rezultirati i povećanjem potrošnje i većim dugom s obzirom da je u takvim okolnostima vladi lakše strateški koristiti javna sredstva kako bi održali parlamentarnu većinu (Tabellini i Alesina, I990; Padovano i Venturi, 200I). Korištene su i sljedeće kontrolne varijable: gdp_gr i pop. Varijabla gdp_gr označava vrijednosti stopa rasta realnog BDP-a, te služi kao proxy varijabla za opći gospodarski razvoj i utjecaj poslovnih ciklusa na rashode. Očekivani predznak uz ovu varijablu može biti pozitivan ili negativan, ovisno o diskrecijskoj fiskalnoj politici. Varijabla pop označava proporciju stanovništva u dobi od 6o godina i više, te se očekuje pozitivni predznak uz ovu varijablu budući da starenje stanovništva stavlja dodatni pritisak na povećanje ukupnih rashoda (prvenstveno kroz izdatke na mirovine i zdravstvenu zaštitu). Kao instrumentalna varijabla koristit će se lagirana vrijednost zavisne varijable s jednim vremenskim pomakom unatrag. Nadalje, valjanost instrumenata koji se odaberu za procjenu modela testira se Sarganovim testom ${ }^{\mathrm{I3}}$. Pored Sarganovog testa, provodi se i testiranje autokorelacije u rezidualima, pomoću testova $m_{\mathrm{I}} \mathrm{i} m_{2}{ }^{\mathrm{I}}$. Analizom je obuhvaćeno razdoblje od 1995. do 20Io. godine, pri čemu su podaci izraženi kao godišnje frekvencije. Analiza završava s 20Io. godinom, budući da podaci za varijable o političkim institucijama za 20II. nisu objavljeni. Izvori originalnih podataka zavisne, te kontrolnih varijabli su Eurostat i Hrvatska narodna banka (HNB), dok su izvori nezavisnih varijabli Svjetska banka (Database of Political Institutions) i Polity IV Project (kao dio Societal-Systems Research Inc i Center for Systemic Peace) čijim je bazama obuhvaćena i Hrvatska. Popis korištenih varijabli i izvora podataka dan je u tablici I.

\footnotetext{
${ }^{12}$ Dodatni razlozi očekivanog negativnog predznaka navedeni su u Aidt i Eterovic (20II).

${ }^{13}$ Naime, Sarganov test koji se koristi za ispitivanje preidentificiranosti ograničenja u statističkom modelu (odnosno validnost instrumentalnih varijabli) temelji se na pretpostavci da bi reziduali trebali biti nekorelirani sa skupom egzogenih varijabli ukoliko su instrumenti doista egzogeni. Specifično, testira se hipoteza da su instrumentalne varijable nekorelirane sa skupom reziduala, te da su u tom smislu prihvatljivi instrumenti.

${ }^{14}$ Nultom hipotezom $m_{I}$ testa pretpostavlja se nepostojanje autokorelacije prvog reda među diferencijama reziduala, a nultom hipotezom $m_{2}$ testa pretpostavlja se nepostojanje autokorelacije drugog reda među diferencijama reziduala (Škrabić, 2009).
} 


\section{TABLICA I.}

Opis varijabli i izvori podataka

\begin{tabular}{|c|c|c|}
\hline Varijabla & Opis varijabli & Izvor \\
\hline $\exp$ & $\begin{array}{l}\text { Vrijednosti ukupnih izdataka opće države } \\
\text { iskazani kao postotak BDP-a }\end{array}$ & Eurostat, HNB \\
\hline herfgov & Vrijednost Herfindahlovog indeksa & Database of Political Institutions \\
\hline polityIV & Stupanj političke konkurencije & Polity IV Project \\
\hline$b d p_{-} g r$ & Vrijednosti stopa rasta realnog BDP-a & Eurostat \\
\hline рор & $\begin{array}{l}\text { Proporcija stanovnistva u dobi od } 60 \\
\text { godina i više }\end{array}$ & Eurostat \\
\hline stabs & Stabilnost političkog sustava & Database of Political Institutions \\
\hline
\end{tabular}

Izvor: Izračun autorica.

\subsection{INTERPRETAGIJA REZULTATA EMPIRIJSKE ANALIZE I IMPLIKAGIJE ZA HRVATSKU}

U ovom dijelu rada sadržani su rezultati provedene panel analize i dijagnostičkih testova. U tablici 2. prikazani su rezultati procjene utjecaja odabranih varijabli na proračunske rashode u zemljama članicama Europske unije i Hrvatskoj. Pri tome je zadovoljena pretpostavka dinamičkog modela i Arellano Bond procjenitelja o nepostojanju autokorelacije između diferencija reziduala. Naime, prihvaća se nulta hipoteza o nepostojanju autokorelacije među diferencijama reziduala drugog reda ${ }^{15}$, uz uobičajenu razinu značajnosti. Također se na osnovi provedenog Sarganovog testa o preidentificiranosti ograničenja prihvaća pretpostavka da ne postoji korelacija između reziduala i instrumenta, što potvrđuje validnost instrumentalne varijable. Zavisna varijabla s vremenskim pomakom statistički je signifikantna i pozitivnog je predznaka. Nadalje, iz tablice je vidljivo da su varijable herfgov, bdp_gr, pop i stabs statistički signifikantne u modelu, te da njihovi koeficijenti imaju očekivane predznake. Rashodi državnog proračuna u zemljama članicama EU i Hrvatskoj pokazali su se dakle, osjetljivima na fragmentaciju vlade i političku (ne)stabilnost. Preciznije, veća fragmentacija vlade (manji indeks) i veća stabilnost političkog sustava (manji stabs) utječu na povećanje državne potrošnje. Također su signifikantne i kontrolne varijable stope rasta BDP-a i starenje stanovništva. Stupanj političke konkurencije (polityIV) i konstantni član nisu signifikantni u analiziranom modelu.

Dobiveni rezultati su u skladu s dosadašnjim teorijskim i empirijskim istraživanjima (primjerice Persson i Tabellini, 2006; Persson, Roland i Tabellini, 2003; Gregorini i Longoni, 2010; Hallerberg i von Hagen, 1997). Međutim, ključno je pitanje koje bi bile normativne implikacije ovog istraživačkog područja. Izborni sustavi (kroz definiranje pravila igre, te ponajviše kroz utjecaj na fragmentiranost vlade), imaju za cilj uspostaviti ravnotežu između predstavništva (engl. representation) i odgovornosti (engl. accountability) koje se općenito uzimaju kao dvije "mjerne jedinice" za ispitivanje uspješnosti demokratskih institucija čiji je trade-off uvjetovan načinom oblikovanja političkog sustava (Persson i Tabellini, 2006). Pri tome, dimenzija izbornih sustava koja privlači najviše pažnje je razmjernost razmjerni sustavi dovode do politički poželjnog povećanja $\mathrm{u}$ predstavništvu, ali $\mathrm{u}$ kombinaciji $\mathrm{s}$

\footnotetext{
${ }^{15}$ Budući da se među rezidualima prvog reda očekuje postojanje autokorelacije, njeno se postojanje najčešće zanemaruje, dok postojanje autokorelacije drugog reda ne upućuje na probleme pri specifikaciji modela, tj. ne pokazuje da neki od uvjeta na momente nisu zadovoljeni (Huang, 2006). Nadalje, unatoč postojanju autokorelacije prvog reda među diferencijama reziduala, uz istodobno ne postojanje autokorelacije drugog reda, GMM procjene su konzistentne (Arellano i Bond, 199I).
} 
neželjenim fiskalnim ishodima pa se postavlja pitanje može li se (i na koji način) ovakav trade-off ublažiti (Fabrizio i Mody, 2007). Prema Nohlenu (1992), budući da izborni sustavi djeluju u složenom okviru povijesnih, društvenih, kulturnih i institucionalno političkih faktora, historijsko-empirijski pristup ključan je za normativna pitanja. Konačno, dizajniranje potencijalnih izbornih reformi obuhvaća dva ključna koraka. Prvi korak odnosi se na znanstveno i političko vrednovanje funkcionalnosti postojećega izbornog sustava dok se $\mathrm{u}$ drugom koraku definiraju ciljevi izborne politike (Kasapović, 2003).

\section{TABLIGA 2.}

Rezultati dinamičkog linearnog panel modela

\begin{tabular}{|c|c|}
\hline Varijable & Rezultati \\
\hline G & $-0,093(0,283)$ \\
\hline $\exp _{t-I}$ & $0,678\left(0,000^{*}\right)$ \\
\hline herfgov & $-2,784\left(\mathrm{O}, \mathrm{OIO}^{*}\right)$ \\
\hline polityIV & $-0,05 \mathrm{I}(0,886)$ \\
\hline$g d p \_g r$ & $-0,329\left(0,0^{*}\right)$ \\
\hline pop & $0,658\left(0,085^{* * *}\right)$ \\
\hline stabs & $-\mathrm{I}, \mathrm{O} 73\left(0,007^{*}\right)$ \\
\hline Broj opservacija & 355 \\
\hline Broj zemalja & 26 \\
\hline Sargan test (p-vrijednost) & $0,524 \mathrm{I}$ \\
\hline Autokorelacija prvog reda (p-vrijednost) & 0,0000 \\
\hline Autokorelacija drugog reda (p-vrijednost) & 0,8278 \\
\hline
\end{tabular}

Napomena: *,*****označava statističku značajnost na razini 1\%, 5\% i Io\%; vrijednosti u zagradama su p-vrijednosti.

Izvor: Izračun autorica.

Dakle, rezultati dobiveni u ovom radu mogu poslužiti kao podloga za znanstveno promišljanje o praktičnoj ulozi političkih institucija u kreiranju ekonomske politike, a mogu imati i bitne implikacije za Hrvatsku s obzirom da se često vode rasprave treba li Hrvatskoj još jedna reforma izbornog sustava.

Naime, u devedesetim su godinama promijenjeni svi glavni modeli sustava izbora: sustav apsolutne većine (I990.), kombinirani sustav s jednakim omjerom većinskih i listovnih mandata (1992.), kombinirani sustav s pretežnim udjelom listovnih mandata (1995.) i razmjerni izborni sustav s višemandatnim izbornim jedinicama, te zatvorenim (blokiranim) listama (200o.) (Kasapović, 200I). Osim toga, 20oo. godine je i polupredsjednički oblik vlasti zamijenjen parlamentarnim čime su ograničene ovlasti Predsjednika i osnažena uloga Vlade. ${ }^{16} \mathrm{~S}$ obzirom da je Hrvatska provela veći broj reformi u relativno kratkom periodu, poželjno je u budućim istraživanjima analizirati reflektiraju li se te reforme u promjenama s aspekta veličine i sastava državne potrošnje, proračunskog salda ili javnog duga. Iako do sada nisu provedena detaljnija istraživana po tom pitanju, može se zaključiti da je reforma na razmjerni izborni sustav iz 200o. godine ipak povećala frekvenciju koalicijskih vlada (od 20oo. godine Hrvatska je imala neki oblik koalicijske vlade) koje prema teorijskim postavkama te rezultatima ekonometrijske analize provedene u ovom radu teže povećanoj državnoj potrošnji. Naime,

${ }^{16}$ Glavna obilježja predsjedničkog oblika vlasti su visoka koncentracija moći u rukama predsjednika kao glavnog aktera u političkom sustavu te personifikacija politike. 
uz češće koalicijske vlade, veća je vjerojatnost da će doći do već spomenutog problema zajedničke blagajne među vladajućim strankama od kojih će svaka nastojati zadovoljiti želje svog biračkog tijela, pa će rasti i ukupna potrošnja (Voigt, 2009). Navedeno je, kroz smanjenje odgovornosti, zasigurno biračima otežalo i donošenje odluka po pitanju koju stranku kazniti (nagraditi) u uvjetima nepovoljnih (dobrih) ekonomskih rezultata te doprinijelo nepovjerenju biračkog tijela prema vladi. Stoga bi rezultati istraživanja dodatno doprinijeli promišljanju o budućim potencijalnim reformama cijelog izbornog sustava (ili njegovih pojedinačnih elemenata) u Hrvatskoj.

\section{ZAKLJUǦNA RAZMATRANJA}

Pregledom teorijskih predviđanja i dosadašnjih empirijskih istraživanja pokazano je da političke institucije utječu na ishode ekonomske politike. Međutim, detaljni mehanizmi kroz koje pojedine institucije utječu na različite ishode su poprilično nejasni te je empirijska literatura iz ovog područja suočena s brojnim izazovima. Rezultati ekonometrijske analize provedene u ovom radu pokazuju da statistički najznačajniji utjecaj na državnu potrošnju imaju fragmentiranost vlade i (ne)stabilnost političkog sustava, što je u skladu s dosadašnjim istraživanjima koji ističu da izborni sustav zapravo ima indirektni utjecaj na ishode politike. Točnije, pokazano je da veća fragmentiranost vlade dovodi do povećanja državne potrošnje. Ovakav rezultat je važan za Hrvatsku koja je u promatranom razdoblju uglavnom imala neki oblik koalicijske vlade koju karakterizira problem zajedničke blagajne te kolektivnog odlučivanja. Međutim, s obzirom da postoje dimenzije izbornih sustava koje nisu uzete u obzir u ovom radu, a koje također mogu imati utjecaj na kreiranje fiskalne politike, kod interpretacije rezultata i donošenja zaključaka o poželjnosti jednog izbornog sustava nad drugim zahtijeva se određena doza opreza.

Uz sva ograničenja provedenog istraživanja (endogenost političkih institucija, veličinu uzorka i vremenski okvir), dobivena saznanja su preliminarna, dok je glavni cilj potaknuti daljnje diskusije na ovom području istraživanja koje do sada u Hrvatskoj nije analizirano na ovaj način. Naime, s negativnim utjecajima globalne ekonomske krize, možemo očekivati da će se pažnja sve više usmjeravati na aspekte pozitivne i normativne konstitucionalne političke ekonomije. 


\section{REFERENCE}

I. Acemoglu, D., 2005. Constitutions, Politics, and Economics: A Review Essay on Persson and Tabellini's the Economic Effects of Constitutions. Journal of Economic Literature, 43(4), IO25-IO48. doi: 10.1257/002205105775362069

2. Acocella, N., 2005. Economic Policy in the Age of Globalisation. Cambridge: Cambridge University Press. doi: 10.1017/CBO9780511753947

3. Aidt, T. S. i Eterovic, D. S., 2OII. Political competition, electoral participation and public finance in 20th century Latin America. European Journal of Political Economy, 27(I), pp. I8I-200. doi: Io.IoI6/j.ejpoleco.20I0.06.006

4. Alesina, A. [et al.], 1999. Budget Institutions and Fiscal Performance in Latin America, Working Paper Series, [online]. Dostupno na: 〈http://www.iadb.org/res/publications/pubfiles/pubwp394.pdf>.

5. Alesina, A. i Perotti, R., 1999. Budget Deficits and Budget Institutions in: J. M. Poterba and J. von Hagen, eds. Fiscal Institutions and Fiscal Performance. Chicago: University of Chicago Press, pp. I336.

6. Arellano, M. i Bond, S., I99I. Some test of specification for Panel data, Monte Carlo Evidence and Application to Employment Equations. Review of Economic Studies, 58(2), pp. 277-297. doi: I0.2307/2297968

7. Beck, T. [et al.], 20oI. New tools in comparative political economy: The Database of Political Institutions. World Bank Economic Review, I5(I), pp. 165-176.

8. Besley, T., Persson, T. i Sturm, D.M., 20Io. Political Competition, Policy and Growth: Theory and Evidence from the United States [online]. Dostupno na: 〈http://econ.lse.ac.uk/ tbesley/papers/bps.pdf >.

9. Blume, L. [et al.], 2007. The Economic Effects of Constitutions: Replicating - and Extending Persson and Tabellini. CESIFO WORKING PAPER, No. 20I7. Dostupno na: <http://www.cesifogroup.de/portal/pls/portal/docs/I/II87570.PDF>.

IO. Bond, S. R., 2002. Dynamic panel data models: a guide to micro data methods and practice. Portuguese Economic Journal, I(2), pp. I4I-I62. doi: I0.I007/sIO258-002-00o9-9

II. Croatian National Bank. Statistical Survey: Government finance. Dostupno na: $\langle$ http://www.hnb.hr/statistika/hstatistika.htm〉.

I2. Devereux, M. B. i Wen, J. F., 1998. Political instability, capital taxation, and growth. European Economic Review, 42, pp. I635-I65I. doi: Io.IoI6/SooI4-292I(97)ooioo-I

I3. Eurostat, 20II. Dostupno na: 〈http://epp.eurostat.ec.euroa.eu>.

I4. Fabrizio, S. i Mody, A., 2007. The Value and Reform of Budget Institutions [online]. Dostupno na: $\langle$ http://papers.ssrn.com/sol3/papers.cfm?abstract_id=2004436〉.

I5. Gregorini, F. i Longoni, E., 20IO. Inequality, Political Systems and Public Spending [online]. Dostupno na: 〈http://www.socpol.unimi.it/papers/20IO-o3-I6_Filippo\%2OGregorini.pdf 〉.

I6. Hallerberg, M. i von Hagen, J., 1997. Electoral Institutions, Cabinet Negotiations, and Budget Deficits in the European Union. NBER Working Paper, No. 634I [online]. Dostupno na: 〈http://www.nber.org/papers/w634I.pdf?new_window=I〉.

I7. Hallerberg, M., Strauch, R. i von Hagen, J., 2007. The design of fiscal rules and forms of governance in European Union countries. European Journal of Political Economy, 23(2), pp. 338-359. doi: IO.IOI6/j.ejpoleco.2006.II.005

I8. Hansen, L., 1982. Large sample properties of generalized method of moments estimators. Econometrica, 5O(3), pp. IO29-IO54. doi: I0.2307/1912775

19. Hellman, J. i Schankerman, M., 2000. Intervention, Corruption and Capture. The nexus between enterprises and state. Economics of Transition, 8(3), pp. 545-576. doi: Io.IIII/I468-0351.00055

20. Huang, W., 2006. Emerging Markets Financial Openness and Financial Development. Working paper No. 06/588. University of Bristol: Department of Accounting and Finance.

21. Kasapović, M., 2003. Izborni leksikon. Zagreb: Politička kultura.

22. Kaspović, M. (ed.), 200I. Hrvatska politika 1990.-2000. Izbori, stranke i parlament u Hrvatskoj, Zagreb: Fakultet političkih znanosti.

23. Klašnja, M., 2008. "Electoral Rules, Forms of Government, and Political Budget Cycles in Transition Countries.” PANOECONOMICUS, 55(2), pp. I85-218. doi: I0.2298/PANo802185K

24. Lohman, S., 2006. The Non-Politics of Monetary Policy in: B. R. Weingast and D. A. Wittman, eds. The Oxford Handbook of Political Economy. Oxford: Oxford University Press, pp. 523-544. 
25. Milesi-Ferretti, G. M., Perotti, R. i Rostagno, M., 2002. Electoral Systems and Public Spending. The Quarterly Journal of Economics, II7(2), pp. 609-657. doi: IO.II62/o03355302753650346

26. Nohlen, D., 1992. Izborno pravoi stranački sustav. Zagreb: Školska knjiga.

27. Padovano, F. and Venturi, L., 200I. Wars of attrition in Italian government coalitions and fiscal performance: 1948-1994. Public Choice,IO9(I-2), pp. 15-54. doi: IO.IO23/A:IOI2OI4I288IO

28. Persson, T. i Tabellini, G., 200o. Political Economics: Explaining Economic Policy. Cambridge, MA: MIT Press.

29. Persson, T. i Tabellini, G., 2003. Economic Effects of Constitutions. Cambridge, MA: MIT Press.

30. Persson, T. i Tabellini, G., 2004a. Constitutional rules and fiscal policy outcomes. American Economic Review, 94(I), pp. 25-64. doi: I0.1257/O0O282804322970689

3I. Persson, T. i Tabellini, G., 2004b. Constitutions and Economic Policy. Journal of Economic Perspectives, I8(I), pp. 75-98. doi: Io.1257/o89533004773563449

32. Persson, T. i Tabellini, G., 2006. Electoral Systems and Economic Policy in B. R. Weingast and D. A. Wittman, eds. The Oxford Handbook of Political Economy. Oxford: Oxford University Press, pp. 723737.

33. Persson, T., 2002. Do Political Institutions Shape economic Policy. Econometrica, 70(3), pp. 883-905. doi: IO.IIII/I468-0262.00313

34. Persson, T., Roland, G. i Tabellini, G., 2003. How do electoral rules shape party structures, government coalitions, and economic policies? [online]. Dostupno na: <http://bcep.haas.berkeley.edu/papers/prt4elrul.pdf $>$.

35. Polity IV Project. Political Regime Characteristics and Transitions I80o-20Io [online]. Available at: 〈http://www.systemicpeace.org/inscr/inscr.htm>.

36. Poterba, J. M., 1994. State Responses to Fiscal Crises: The Effects of Budgetary Institutions and Politics. Journal of Political Economy, IO2(4), pp. 799-82I. doi: 10.IO86/261955

37. Roberts Clark, W., Golder, M. i Nadenichek Golder, S., 2009. Principles of Comparative Politics. Washington: CQ Press.

38. Roodman, D., 2006. "How to Do xtabond2: An Introduction to "Difference" and "system" GMM in Stata" Working Paper Number I03, Center for Global Development.

39. Roubini, N. and Sachs, J. D., 1989. Political and Economic Determinants of Budget Deficits in the Industrial Democracies. European Economic Review, 33(5), pp. 903-938. doi: Io.IoI6/oor42921(89)90002-O

40. Rubil, I. i Švaljek, S., 2OIo. Medium-term Fiscal Prospects in Croatia: Some Back-of-the-envelope Calculations and a Case for Fiscal Rules. Conference Fiscal Policy in the Crisis and Beyond. Short-term Impacts and Long-term Implications [online]. Dostupno na: 〈http://www.eizg.hr/hrHR/Medunarodna-konferencija-EIZ-a-6o2.aspx>.

4I. Škrabić, B., 2009. Determinante razvoja financijskog sustava zemalja središnje i istočne Europe. Ph. D. University of Zagreb.

42. Snowdon, B. i Vane, H., 2005. Modern Macroeconomics: Its Origins, Development and Current State. Edward Elgar, Cheltenham, UK.

43. Tabellini, G. i Alesina, A., I99o. Voting on the budget deficit. American Economic Review, 8o(I), pp. 37-49. Dostupno na: <http://dash.harvard.edu/bitstream/handle/I/4553030/alesina_votingbudget.pdf?sequence $=2>$.

44. Voigt, S., 2009. Positive Constitutional Economics II-A Survey of Recent Developments. Joint Discussion Paper Series in Economics No. 36-2009 [online]. Dostupno na: 〈http://www.unimarburg.de/fbo2/makro/forschung/magkspapers/36-20o9_voigt.pdf>.

45. von Hagen, J., 2006. Political Economy of Fiscal Institutions, in B. R. Weingast and D. A. Wittman, eds. The Oxford Handbook of Political Economy. Oxford: Oxford University Press, pp. 464-478. 